\title{
Pengembangan Buku Ajar Biologi Topik Ekologi Kelas Vii SMP Berbasis Penemuan Terbimbing dengan Memanfaatkan Lingkungan Kebun Sayur
}

\author{
Tresia Valentina Br Depari*, Binari Manurung, Mufti Sudibyo \\ Program Studi Pendidikan Biologi, Program Pascasarjana, Universitas Negeri Medan, Sumatera Utara, \\ *Email: tere_depariunair@yahoo.co.id
}

\begin{abstract}
This study aim to generate a decent textbook to use, easy to learn and can be used for leaners individual learning which produce teaching materials based on guided discovery. This research is the development of a research model product development Borg and Gall combined with a model of Dick and Carey instructional design. The research method consisted of: (1) validation of subject matter experts; (2) validation of expert instructional design; (3) validation of biology teacher; (4) individual trial; (5) small group testing; (6) limited field trials. Test subjects consisted of two subject matter experts biology, one expert instructional design, three students for individual trials, nine students to test small group and 38 students to a limited field test. Value about the quality of the product development is collected by questionnaire and analyzed with quantitative analysis techniques descriptive. The result showed: (1) subject matter experts are very well qualifications $(90,14 \%)$; (2) test of instructional design experts are very well qualifications $(88,06 \%)$; (3) biology teachers are in very well qualifications (93\%); (4) individual trials are in well qualifications (91,07\%); (5) small group trials are in very well qualifications $(90,67 \%)$; (6) limited group trial in very good qualifications $(87,55 \%)$.
\end{abstract}

Keywords: Teaching materials, ecological topics, vegetable garden, guided discovery

\section{PENDAHULUAN}

Pendidikan merupakan bagian penting dari proses pembangunan nasional suatu bangsa dan negara. Dalam pembangunan nasional, sumber daya manusia yang berkualitas mutlak diperlukan. Salah satu wahana untuk mencetak sumber daya manusia yang berkualitas adalah melalui pendidikan. Pendidikan adalah alat untuk mencerdaskan bangsa. Berdasarkan hal tersebut, peningkatan mutu pendidikan sangat diperlukan saat ini. Tantangan kemajuan teknologi dan arus globalisasi menuntut para pendidik untuk dapat menghasilkan siswa sebagai sumber daya manusia yang memiliki pengetahuan tinggi dan keterampilan agar mampu menjawab tantangan tersebut (Anita, 2008).

Pembelajaran yang selama ini diterima siswa hanyalah penonjolan tingkat hafalan dari sekian rentetan topik atau pokok bahasan tanpa diikuti dengan pemahaman yang mendalam (Masnur, 2007). Dalam upaya meningkatkan mutu pendidikan di Indonesia, pemerintah menerbitkan Peraturan Pemerintah (PP) nomor 19 tahun 2005 pasal 20 yang mengisyaratkan bahwa guru diharapkan mengembangkan materi pembelajaran. Berdasarkan hal tersebut guru diharapkan untuk mengembangkan bahan ajar sebagai salah satu sumber belajar. Kemampuan guru dalam merancang bahan ajar menjadi hal yang sangat berperan dalam menentukan keberhasilan proses belajar dan pembelajaran melalui sebuah bahan ajar.

Pengembangan bahan ajar merupakan salah satu bentuk dari kegiatan proses pembelajaran untuk memperbaiki atau meningkatkan kualitas pembelajaran yang berlangsung. Pemerintah menyatakan bahwa bahan ajar yang dikembangkan oleh guru dapat disesuaikan dengan karakteristik siswa sehingga memudahkan siswa untuk memahami substansi dari materi pembelajaran tersebut (Trisnaningsih, 2007).

Salah satu metode yang dapat menjadikan siswa lebih aktif selama pembelajaran berlangsung adalah metode penemuan terbimbing. Dalam pembelajaran dengan metode penemuan terbimbing, siswalah yang aktif mencari konsep materi yang akan dipelajari. Seperti yang 
dikatakan oleh Karim (2011) bahwa pembelajaran dengan metode penemuan merupakan salah satu cara untuk menyampaikan ide/gagasan dengan proses menemukan, dalam proses ini siswa berusaha menemukan konsep dengan bimbingan guru. Guru hanya berperan sebagai fasilitator serta melakukan bimbingan dan bukanlah sebagai satusatunya sumber informasi.

Dengan adanya peran siswa dalam pencarian informasi, dengan hal diharapkan keaktifan dan kemampuan berpikir kritis siswa akan meningkat dan nantinya dapat berpengaruh pula terhadap hasil belajar. Penelitian yang dilakukan oleh Estuningsih, dkk (2013) dengan menerapkan metode pembelajaran penemuan terbimbing dan dipadu dengan pengembangan LKS pada materi substansi genetika, ketuntasan siswa dalam belajar mencapai $83 \%$.

Berdasarkan latar belakang diatas, maka peneliti ingin mengembangkan bahan ajar berbasis penemuan terbimbing di SMP Negeri 3 Berastagi. SMP Negeri 3 Berastagi terletak di dataran tinggi Kabupaten Karo dan berada pada daerah pertanian yang dekat dengan lingkungan kebun wortel, kebun sayur, kebun bunga, ladang jeruk, ladang kopi, ladang padi, dan kebun lainnya. Suratsih dan Wuryadi (dalam Suratsih, dkk., 2009) menambahkan bahwa pembelajaran biologi di sekolah hendaknya terkait dengan lingkungan yang nyata dalam kehidupan sehari-hari atau yang ada di sekitar siswa akan memberikan pengalaman yang tinggi nilainya kepada anak didik. Sedang bahan pelajaran yang ada saat ini tidak semuanya memuat masalah-masalah yang dekat dengan keseharian siswa.

SMP Negeri 3 Berastagi memiliki potensi lokal mendukung dalam proses pembelajaran biologi yang langsung terjun kelapangan. Potensi lokal yang demikian dapat dimanfaatkan sebagai sumber bahan ajar khususnya Topik Ekologi.

Topik Ekologi adalah salah satu materi dalam pelajaran biologi yang dapat memanfaatkan lingkungan sebagai objek pembelajaran dan diajarkan dengan menggunakan metode pembelajaran penemuan terbimbing. Pentingnya pembelajaran penemuan terbimbing dan lingkungan sekitar sekolah yang mendukung, menjadikan pengembangan bahan ajar yang berbasis penemuan terbimbing perlu untuk dilakukan. Salah satu contoh ekologi yang dapat dimanfaatkan sebagai sumber bahan ajar adalah ekologi kebun sayur. Topik Ekologi kebun sayur ini dapat dimanfaatkan sebagai pengenalan terhadap struktur populasi kebun sayur, spesies ekologi kebun sayur, interaksi antar makhluk hidup di kebun sayur, komunitas, aliran energi, piramida makanan dan faktor lain yang mempengaruhi ekologi kebun sayur.

Pada penelitian ini, peneliti memanfaatkan lingkungan sekitar yaitu kebun sayur sebagai sumber bahan ajar Topik Ekologi dengan model penemuan terbimbing. Lingkungan sekitar yang demikian dapat dimanfaatkan secara optimal untuk belajar secara penemuan dengan melibatkan siswa secara langsung dengan lingkungan sehingga siswa menjadi lebih aktif dalam proses pembelajaran dan berlatih bertanggungjawab terhadap proses belajarnya masing-masing seperti yang telah disampaikan oleh Akinoglu dan Tandogan (2007).

Dari hasil penelitian ini diharapkan siswa dapat memahami, menginvestigasi dan menemukan konsep ekologi kebun sayur. Hal yang akan dipahami mulai dari komponen penyusun ekologi kebun sayur, pengaruh lingkungan terhadap ekologi kebun sayur, interaksi antar makhluk hidup penyusun ekologi kebun sayur, piramida ekologi kebun sayur, aliran energi ekologi kebun sayur dan hal lain yang ditemukan sendiri oleh siswa pada ekologi kebun sayur.

\section{METODE PENELITIAN}

Jenis penelitian ini adalah penelitian deskriptif kualitatif. Penelitian ini dilakukan di kebun sayur, yang terletak di Kabupaten Karo dan SMP Negeri 3 Berastagi pada Februari 2016 sampai April 2016.

Pengembangan bahan ajar topik Ekologi ini menggunakan model pengembangan Borg dan Gall. Penelitian 
pengembangan atau Research and Development adalah penelitian yang digunakan untuk menghasilkan produk tertentu, dan menguji keefektifan produk tertentu (Sugyono, 2011).

Adapun langkah-langkah dari tahapan pengembangannya sebagai berikut: a. Melakukan penelitian pendahuluan, yaitu meliputi: (1) identifikasi kebutuhan atau tujuan pembelajaran dan memenentukan standar kompetensi mata pelajaran, (2) melakukan analisis pembelajaran dengan menentukan keterampilan yang lebih khusus yang harus dipelajari, mengidentifikasi karakteristik dan perilaku awal peserta didik, dan (4) menulis kompetensi dasar dan indikatornya, b. Mengembangkan butir penilaian untuk mengukur kemampuan peserta didik yang diperkirakan didalam tujuan pembelajaran; c. Pengumpulan bahan, meliputi: (1) pengumpulan materi pembelajaran, (2) pembuatan dan pengumpulan gambar (ilustrasi); d. Pengembangan bahan ajar; e. Validasi produk; f. Revisi Produk; dan g. Uji coba produk. Produk yang dikembangkan dalam penelitian ini adalah bahan ajar pada topik Ekologi Kebun Sayur Berbasis penemuan terbimbing (Guided Discovery).

Teknik pengumpulan data dengan cara angket. Ada empat jenis angket yang digunakan untuk menjaring informasi dan data kelayakan yang diperlukan dalam pengembangan bahan ajar yang disusun berdasarkan kesesuaian informasi bagi siswa yaitu angket A (ahli materi), B (ahli desain), C (guru biologi) dan D (siswa).

Data yang diperoleh adalah data tentang keadaan bahan ajar. Teknik analisis data yang digunakan untuk mengolah data hasil pengembangan yaitu analisis deskriptif. Data ini dikumpulkan melalui lembar validasi ahli materi, ahli desain, guru, uji lapangan. Uji lapangan terdiri dari: uji coba perorangan (3 orang siswa), uji coba kelompok kecil (9 orang siswa) dan uji coba kelompok terbatas (38 orang siswa).

\section{HASIL DAN PEMBAHASAN Hasil}

Perolehan data penelitian dengan judul "Pengembangan Bahan Ajar Topik Ekologi Kelas VII SMP/MTs Berbasis Penemuan Terbimbing dengan Memanfaatkan Kebun Sayur" ini berasal dari empat sumber data analisis yang diperoleh dari empat angket (angket A, B, C, dan D). Sumber keempat angket ini yaitu dari lembar validasi yang diisi oleh tim ahli materi (angket A), validasi oleh tim ahli desain (angket B), uji coba guru bidang studi biologi (angket C), dan uji coba lapangan oleh siswa (angket D).

Hasil Validasi Bahan Ajar dengan judul "Pengembangan Bahan Ajar Topik Ekologi Kelas VII SMP/MTs Berbasis Penemuan Terbimbing dengan Memanfaatkan Kebun Sayur" Oleh Tim Ahli Materi dapat dilihat pada Tabel 1.

Tabel 1. Penilaian oleh Ahli Materi Terhadap Bahan Ajar Ekologi Kebun Sayur Berbasis Penemuan Terbimbing

\begin{tabular}{|c|c|c|c|c|}
\hline \multirow{2}{*}{$\begin{array}{l}\text { Penilaian } \\
\text { Indikator }\end{array}$} & \multicolumn{2}{|c|}{ Indikator } & & \\
\hline & \multicolumn{2}{|c|}{ I } & \multicolumn{2}{|c|}{ II } \\
\hline Ahli Materi & 1 & 2 & 1 & 2 \\
\hline Skor & 81 & 86 & 54 & 53 \\
\hline$\%$ Penilaian & \multicolumn{2}{|c|}{$90,80 \%$} & \multicolumn{2}{|c|}{$89,17 \%$} \\
\hline Rata-rata $\%$ penilaian & \multicolumn{4}{|c|}{$89,96 \%$} \\
\hline Kriteria & \multicolumn{4}{|c|}{ Sangat Baik } \\
\hline
\end{tabular}

Persentase penilaian kelayakan isi bahan ajar oleh kedua ahli materi terhadap dua indikator isi produk pengembangan bahan ajar diatas (Tabel 1) diperoleh rata- rata berkisar antara 89,96\%. Ini artinya pada indikator tersebut telah memenuhi kriteria "Sangat Baik". Kriteria sangat baik ini menyatakan bahwa materi pada bahan 
ajar yang dikembangkan ini dinyatakan layak. Persentase validasi isi bahan ajar oleh tim ahli materi pembelajaran terhadap bahan ajar ekologi kebun sayur berbasis penemuan terbimbing dari kedua tim ahli materi tersebut dapat digambarkan seperti pada Gambar 1.

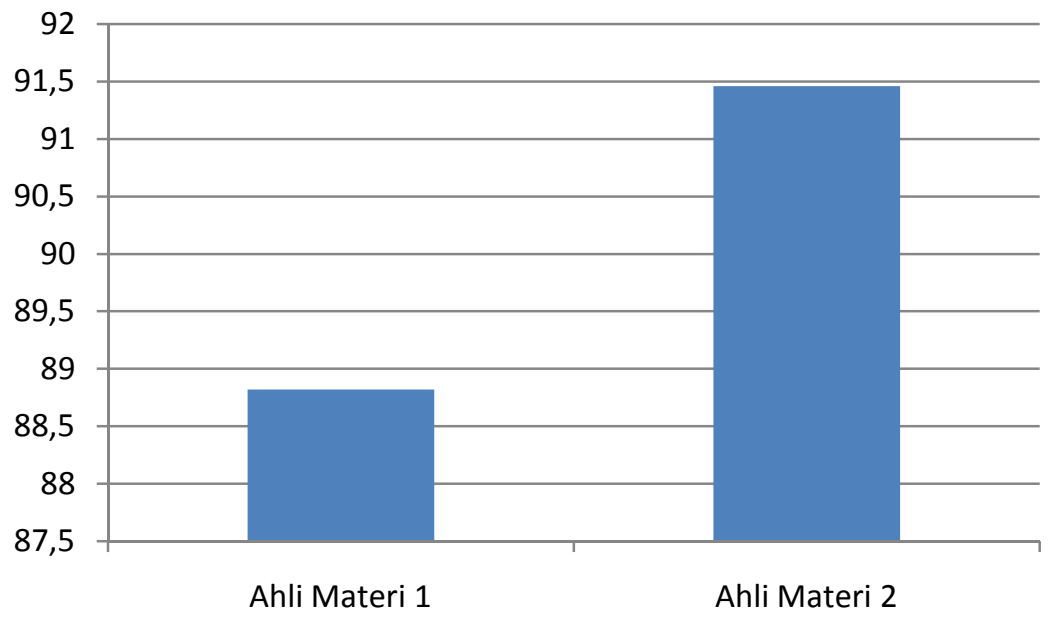

Gambar 1. Persentase validasi isi bahan ajar materi terhadap bahan ajar ekologi kebun sayur berbasis penemuan terbimbing oleh tim ahli materi.

Dari gambar diatas dapat dilihat bahwa hasil persentase ahli materi pertama terhadap bahan ajar sebesar 88,82\% dengan kategori sangat baik, sehingga bahan ajar yang dikembangkan dinyatakan layak. Hasil persentase ahli materi kedua terhadap bahan ajar sebesar 91,46\% dengan kategori "Sangat Baik", sehingga bahan ajar yang dikembangkan dinyatakan layak. Persentase rata-rata kelayakan materi bahan ajar ekologi kebun sayur berbasis penemuan terbimbing dari kedua ahli materi sebesar 90,14\% dengan kategori sangat baik, sehingga bahan ajar yang telah dikembangkan dinyatakan layak.
Validasi terhadap desain produk dimaksudkan untuk mengetahui pendapat ahli desain tentang rancangan bahan ajar. Validasi ahli desain terhadap pengembangan bahan ajar ekologi kebun sayur berbasis penemuan terbimbing ini dilakukan oleh bapak Dr. Rachmad Mulyana, M.Pd yang merupakan dosen teknologi pendidikan Pascasarjana Universitas Negeri Medan. Hasil dari lembar penilaian dari angket B disajikan pada Tabel 4.2 yang merupakan hasil penilaian ahli desain.

Tabel 2. Penilaian oleh Ahli Desain Desain Bahan Ajar

\begin{tabular}{llll}
\hline Penilaian & Indikator & & \\
\hline Indikator & I & II & III \\
\hline Skor & 11 & 34 & 49 \\
\hline$\%$ Penilaian & $91,70 \%$ & $85 \%$ & $87,50 \%$ \\
\hline Rata-rata \% penilaian & $88,06 \%$ & & \\
\hline Kriteria & Sangat Baik & & \\
\hline
\end{tabular}

Persentase penilaian desain bahan ajar Biologi SMP pada topik Ekologi Kebun Sayur Berbasis Penemuan Terbimbing oleh ahli desain biologi pengembangan bahan ajar diatas diperoleh rata-rata $88,06 \%$, artinya pada indikator tersebut bahan ajar dinyatan "Sangat Baik". Kriteria sangat baik telah memenuhi kriteria dan desain bahan ajar yang dikembangkan tersebut dinyatakan layak.

Dari hasil validasi oleh dua guru bidang studi biologi disimpulkan bahwa bahan ajar biologi SMP berbasis penemuan terbimbing topik ekologi kebun sayur 
berada pada kriteria "Sangat Baik" dengan rata-rata persentase 93\% (Tabel 3).

Tabel 3. Penilaian Oleh Guru Biologi Terhadap Bahan Ajar

\begin{tabular}{lcc}
\hline Penilaian Guru & $\mathbf{1}$ & $\mathbf{2}$ \\
\hline Skor Total & 59 & 60 \\
\hline$\%$ Penilaian & $92,19 \%$ & $93,75 \%$ \\
\hline Rata-rata \% penilaian & \multicolumn{3}{c}{$93 \%$} \\
\hline Kriteria & \multicolumn{3}{c}{ Sangat Baik } \\
\hline
\end{tabular}

Data uji coba perorangan dilakukan di SMP Negeri 3 Berastagi. Uji coba ini dilakukan terhadap tiga orang siswa kelas VII Reguler (VII-4) dengan kemampuan rendah, sedang, dan tinggi. Ini ditujukan untuk mengidentifikasi kekurangan produk dan tanggapan siswa terhadap produk yang dikembangkan. Penilaian perorangan siswa terhadap bahan ajar biologi topik ekologi kebun kubis berbasis penemuan terbimbing yang dikembangkan dapat dilihat pada Tabel 4 berikut ini.

Tabel 4. Penilaian Uji Perorangan Oleh Siswa Terhadap Bahan Ajar

\begin{tabular}{lccc}
\hline Penilaian Perorangan & \multicolumn{3}{c}{ Siswa (3 orang) } \\
\cline { 2 - 4 } & $\mathbf{1}$ & $\mathbf{2}$ & $\mathbf{3}$ \\
\hline Skor Total & 50 & 52 & 51 \\
\hline \% Penilaian & $89,29 \%$ & $92,86 \%$ & $91,07 \%$ \\
\hline Rata-rata \% penilaian & \multicolumn{3}{c}{$91,07 \%$} \\
\hline Kriteria & \multicolumn{3}{c}{ Sangat Baik } \\
\hline
\end{tabular}

Dari hasil uji coba perorangan disimpulkan bahwa bahan ajar yang dikembangkan berada pada kriteria "Sangat Baik", dengan rata-rata persentase $91,07 \%$ dan dinyatakan layak. Data uji coba kelompok kecil dilakukan di SMP Negeri 3
Berastagi. Uji coba ini dilakukan terhadap sembilan orang siswa kelas VII Reguler (VII-4) dengan kemampuan rendah, sedang, dan tinggi dandapat dilihat pada Tabel 5 berikut ini.

Tabel 4. Penilaian Uji Kelompok Kecil Oleh Siswa Terhadap Bahan Ajar

\begin{tabular}{llllllllll}
\hline Penilaian kelompok kecil & \multicolumn{10}{c}{ Siswa (9 orang) } \\
\cline { 2 - 10 } & 1 & 2 & 3 & 4 & 5 & 6 & 7 & 8 & 9 \\
\hline Skor Total & 51 & 47 & 53 & 54 & 49 & 50 & 50 & 52 & 51 \\
\hline \% Penilaian & 91,07 & 83,93 & 94,64 & 96,43 & 87,50 & 89,30 & 89,29 & 92,86 & 91,07 \\
\hline Rata-rata \% Penilaian & 90,67 & & & & & & & & \\
\hline Kriteria & \multicolumn{1}{l}{ Sangat Baik } & \multicolumn{10}{c}{}
\end{tabular}

Dari hasil uji coba kelompok kecil disimpulkan bahwa bahan ajar yang dikembangkan berada pada kriteria sangat baik, dengan rata-rata persentase 90,67\% dan dinyatakan "Sangat Baik" dan dinyatakan layak. Data uji coba kelompok terbatas dilakukan di SMP Negeri 3 Berastagi. Uji coba ini dilakukan terhadap 38 orang siswa kelas VII Reguler dan dapat dilihat pada Tabel 6 berikut ini.

Tabel 5. Penilaian Uji Kelompok Terbatas Oleh Siswa Terhadap Bahan Ajar

\begin{tabular}{ll}
\hline Penilaian Kelompok Terbatas & Siswa (38 orang) \\
\hline Skor Total & 1863 \\
\hline Rata-rata \% penilaian & $87,67 \%$ \\
\hline Kriteria & Sangat Baik \\
\hline
\end{tabular}


Dari hasil uji coba kelompok terbatas disimpulkan bahwa bahan ajar yang dikembangkan berada pada kriteria sangat baik, dengan rata-rata persentase $87,67 \%$ dan dinyatakan "Sangat Baik" dan dinyatakan layak. Dari ketiga uji coba lapangan tersebut, terlihat persentase penilaian siswa terhadap bahan ajar topik ekologi kebun sayur berbasis penemuan terbimbing yang telah dikembangkan. Hasil dan analisis penilaian siswa dari ketiga uji coba tersebut dapat dilihat pada Tabel 4.7 dibawah ini.

Tabel 6. Penilaian Uji Lapangan Terhadap Pengembangan Bahan Ajar Topik Ekologi Kebun Sayur

\begin{tabular}{llll}
\hline Uji Lapangan & Uji Perorangan & Uji Kelompok Kecil & Uji Kelompok Terbatas \\
\hline Skor Total & 153 & 457 & 1863 \\
\hline$\%$ Penilaian & 91,07 & 90,67 & 87,55 \\
\hline
\end{tabular}

Dari tabel penilaian uji lapangan diagram batang seperti pada gambar tersebut terhadap bahan ajar, dapat dibuat dibawah ini.

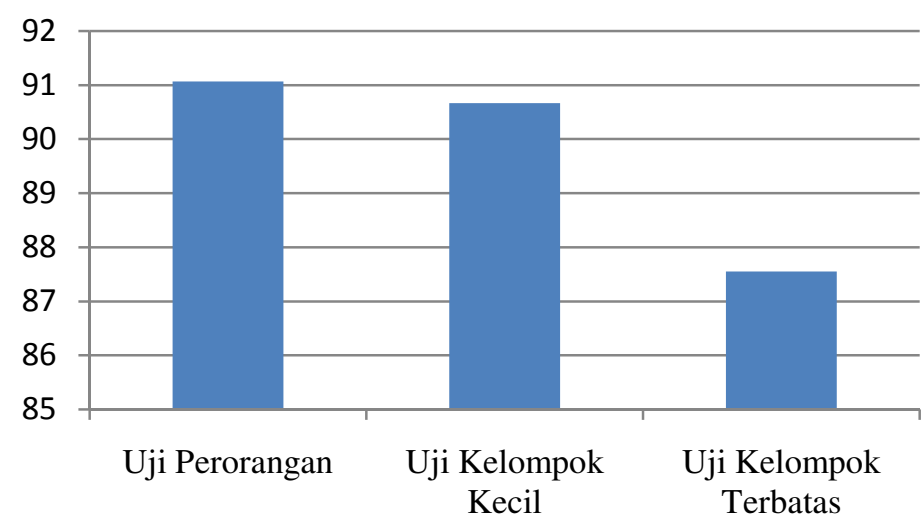

Gambar 2. Persentase uji lapangan bahan ajar ekologi kebun sayur berbasis penemuan terbimbing

Dari uji lapangan tersebut dapat dilihat bahwa demikian produk bahan ajar hasil pengembangan ini layak digunakan sebagai sumber bahan ajar bacaan dalam belajar untuk topik ekologi kebun sayur pada kelas VII SMP/MTs. Pengembangan bahan ajar topik ekologi kebun kubis ini dinyatakan layak oleh tim ahli materi, ahli desain, guru biologi, dan uji lapangan (siswa). Persentase hasil penilaian dari tim ahli materi, ahli desain, guru biologi, dan uji lapangan (siswa) dapat dilihat pada Gambar 3 dibawah ini.

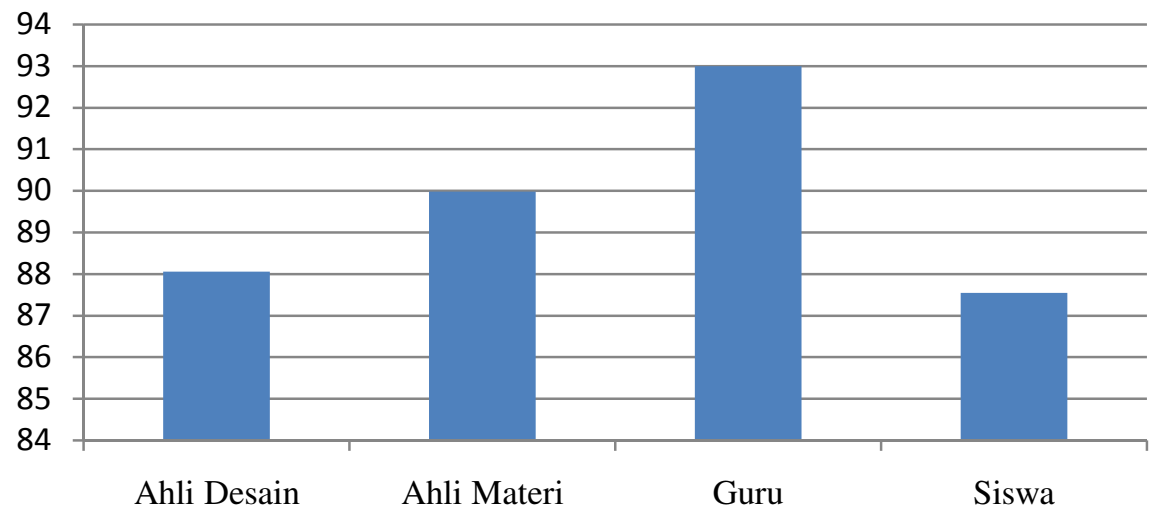

Gambar 3. Persentase penilaian ahli materi, ahli desain, guru biologi, dan uji lapangan (siswa) terhadap bahan ajar ekologi kebun sayur berbasis penemuan terbimbing 


\section{PEMBAHASAN}

Bahan ajar yang telah dikembangkan divalidasikan oleh tim ahli materi dan ahli desain untuk mengetahui kelayakan bahan ajar tersebut. Selanjutnya, bahan ajar yang telah divalidasi oleh ahli materi dan ahli desain tersebut akan dinilai oleh guru biologi dan siswa. Penilaian oleh ahli materi, ahli desain, guru biologi, dan siswa dinilai berdasarkan beberapa indikator.

Hasil persentase dari kedua indikator ahli materi pertama adalah $88,82 \%$ dengan kategori sangat baik, sehingga bahan ajar yang dikembangkan dinyatakan layak. Hasil persentase dar kedua indikator ahli materi kedua terhadap bahan ajar sebesar $91,46 \%$. Jadi, rata-rata hasil validasi dari ahli materi pembelajaran biologi terhadap terhadap kedua indikator tersebut dinilai sangat bagus dengan persentase $90,14 \%$ dan layak.

Hasil validasi dari ahli desain pembelajaran ajar biologi berbasis penemuan terbimbing yang dikembangkan terkait indikator pertama, yaitu format bahan ajar dari bahan ajar biologi berbasis penemuan terbimbing yang dikembangkan sangat baik dengan persentase $91,70 \%$. Hasil validasi dari ahli desain pembelajaran ajar biologi berbasis penemuan terbimbing yang dikembangkan terkait indikator kedua, yaitu: tata letak sampul dan tipografi sampul dari bahan ajar biologi berbasis penemuan terbimbing yang dikembangkan sangat baik dengan persentase $85 \%$.

Hasil validasi dari ahli desain pembelajaran ajar biologi berbasis penemuan terbimbing yang dikembangkan terkait indikator ketiga, yaitu: tata letak buku, tipografi buku, dan ilustrasi buku dari bahan ajar biologi berbasis penemuan terbimbing yang dikembangkan sangat baik dengan persentase 87,5\%.Jadi, hasil validasi dari ahli desain pembelajaran biologi terhadap terhadap ketiga indikator tersebut dinilai sangat bagus dengan persentase $88,07 \%$ dan layak.

Hasil penilaian dari 2 orang guru biologi SMP Negeri 3 Berastagi pada uji coba guru, dinyatakan bahwa bahan ajar biologi berbasis penemuan terbimbing pada topik ekologi kebun sayur yang dikembangkan termasuk kategori sangat baik dengan rata-rata persentase $93 \%$ sehingga dapat diterima dan layak digunakan dalam proses pembelajaran biologi.

Hamalik (2007) yang menyebutkan bahwa pengajaran yang menyediakan kesempatan siswa untuk belajar sendiri atau melakukan aktivitas sendiri adalah pengajaran yang efektif. Hasil tanggapan siswa SMP Negeri 3 Berastagi pada uji coba perorangan dinyatakan bahwa bagan ajar biologi SMP Berbasis Penemuan Terbimbing yang telah dikembangkan termasuk kategori sangat baik dengan ratarata persentase 91,07\%. Pada uji coba kelompok kecil dinyatakan bahwa bagan ajar biologi SMP Berbasis Penemuan Terbimbing yang telah dikembangkan termasuk kategori sangat baik dengan ratarata persentase $90,67 \%$.

Hasil tanggapan siswa SMP Negeri 3 Berastagi pada uji coba kelompok terbatas dinyatakan bahwa bagan ajar biologi SMP Berbasis Penemuan Terbimbing yang telah dikembangkan termasuk kategori sangat baik dengan rata-rata persentase $87,55 \%$. Dari hasil validasi dan penilaian oleh ketiga uji coba lapangan tersebut diperoleh bahwa, bahan ajar yang dikembangkan peneliti "Layak" untuk digunakan sebagai buku pendamping dalam pembelajar biologi di kelas.

Hasil angket tanggapan siswa menunjukan bahwa respon siswa terhadap bahan ajar yang dikembangkan sangat baik. Hal ini sesuai dengan hasil penelitian Sudibyo (2005) yg menunjukan bahwa seperangkat pembelajaran IPA Terpadu yang telah dikembangkan dapat digunakan dengan baik dan siswa menikmati suasana pembelajaran. Dari hasil penilaian yang telah dilakukan oleh ahli materi pembelajaran diperoleh hasil $90,14 \%$, ahli desain pembelajaran diperoleh hasil $88,07 \%$, dua guru bidang studi biologi diperoleh hasil $93 \%$, uji coba perorangan diperoleh hasil 91,07\%, uji coba kelompok kecil diperoleh hasil 90,67\%, uji coba kelompok terbatas diperoleh hasil $87,55 \%$ 
terhadap bahan ajar biologi berbasis penemuan terbimbing. Persentase penilaian secara keseluruhan adalah $87,55 \%$ dengan kategori "Sangat Baik" sehingga buku yang dikembangkan peneliti disimpulkan "Layak" sebagai buku pendamping dalam pembelajar biologi di kelas.

Meskipun mendapatkan skor yang tinggi namun tetap dilakukan revisi pada bahan ajar ini. Hal ini didasarkan pada pertimbangan masukan yang diberikan oleh pakar. Revisi yang diberikan oleh pakar meliputi: melengkapi lembar kegiatan untuk memperjelas konsep penemuan terbimbing untuk memudahkan siswa dalam melakukan pengamatan, melengkapi daftar isi sesuai kerangka penemuan terbimbing, menambahkan kotak glosarium untuk menambah pengetahuan siswa, membuat lembar kegiatan di awal sebelum pemberian konten atau materi, membuat kalimat aktif di setiap perintah kegiatan dan menggunakan siswa sebagai subjek, membuat pertanyaan tantangan pada buku, menambahkan penguatan konsep yang penting, menghilangkan kata yang di awal kalimat, menggunakan ukuran kalimat satu spasi pada keterangan gambar, menggunakan warna hitam putih pada tabel pengamatan, keterangan gambar harus konsisten dan diletakkan di bawah gambar, kolom kalimat pada buku harus konsisten (1 kolom atau 2 kolom), harus menunjukkan ekologi kebun kubis pada cover, ukuran gambar piramida makanan dibuat lebih besar agar terlihat jelas, memperhatikan komposisi gambar, menghilangkan ruang yang kosong, menggunakan huruf italic pada kata ilmiah dan menebalkan kata asing atau istilah penting, dan mengatur cara penarikan gambar agar ukuran gambar sesuai.

Setelah melakukan tahap revisi, maka bahan ajar ekologi kebun sayur berbasis penemuan terbimbing yang dikembangkan ini, dinilai oleh tim ahli materi dan ahli desain. Pada saat proses validasi produk, siswa memberikan tanggapan sangat tertarik untuk membaca bahan ajar yang dikembangkan karena ketika dilihat dari penampilan cover dan gambar telah menarik siswa untuk mengetahui isi bahan ajar tersebut lebih lanjut.Disamping itu, penyajian bahan ajar biologi yang dikembangkan juga dinilai menarik perhatian siswa karena tampilan bahan ajar yang penuh warna dan objek yang diamati dekat dengan kehidupan sehari-hari peserta didik.

\section{KESIMPULAN}

Berdasarkan hasil penelitian dan pembahasan yang telah diuraikan, maka diperoleh kesimpulan bahwa produk akhir bahan ajar biologi topik ekologi kebun sayur berbasis penemuan terbimbing bagi kelas VIISMP/MTs berbasis penemuan terbimbing dinilai layak sebagai bahan bacaan untuk siswa SMP. Hal ini didukung oleh hasil validasi Dari hasil penilaian yang telah dilakukan oleh ahli materi pembelajaran diperoleh hasil 90,14\% dengan kategori sangat baik, ahli desain pembelajaran diperoleh hasil $87,50 \%$ dengan kategori sangat baik, dua guru bidang studi biologi diperoleh hasil 93\% dengan kategori sangat baik, uji coba perorangan diperoleh hasil $91 \%$ dengan kategori sangat baik, uji coba kelompok kecil diperoleh hasil $90,67 \%$ dengan kategori sangat baik, uji coba kelompok terbatas diperoleh hasil $87,55 \%$ dengan kategori sangat baik terhadap bahan ajar biologi berbasis penemuan terbimbing. Persentase penilaian secara keseluruhan terhadap buku ajar kebun sayur yang dikembangkan berbasis penemuan terbimbing ini adalah $89,98 \%$ dengan kategori sangat baik dan dinyatakan layak.

\section{DAFTAR PUSTAKA}

Anita, L. 2008. Memudahkan anak belajar. Jakarta : Kompas.

Dick, W., \& Carey, L. 2001. The Systematic Design of Instruction. Addison-Wesley Educational Publisher Inc.

Estuningsih, Silvia.dkk. 2013. Pengembangan Lembar Kerja Siswa (LKS) Berbasis Penemuan Terbimbing (Guided Discovery) untuk Meningkatkan Hasil belajar Peserta Didik Kelas XIII IPA SMA Pada Materi Substansi Genetika. FMIPA UNESA.

Mansur, Muslich. 2007. KTSP. Pembelajaran Berbasis kompetensi dan Konstektual. 
Jurnal Pendidikan Biologi, Vol. 6, No. 1, Edisi Desember 2016

Paduan bagi Guru, Kepala Sekolah, dan Pengawas Sekolah. Jakarta: Bumi Aksara.

Suratsih, dkk. 2009. Pengembangan Modul Pembelajaran Genetika Berbasis Fenomena Lokal. Jurnal FMIPA Universitas Negeri Yogyakarta.

Trianto. (2011). Pengantar Penelitian Pendidikan Bagi Pengembangan Profesi
Pendidikan dan Tenaga Kependidikan. Jakarta: Kencana.

Trisnaningsih. 2007. Pengembangan Bahan Ajar Untuk Meningkatkan Pemahaman Materi Mata Kuliah Demografi Teknik. Jurnal Ekonomi \& Pendidikan, 4 (2). 